\title{
Contornos do Indizível: o estilo de Clarice Lispector
}

Ana Augusta Wanderley Rodrigues de Miranda

Resumo

O indizível é transmitido por elementos específicos na escrita de Clarice Lispector, e o estilo da autora gira em torno dessa transmissão. É possível aproximar os termos estilo, indizível e transmissão da noção psicanalítica de Real e detectar, nos referidos elementos, grande semelhança com a noção lacaniana de letra.

Palavras-chave: Indizível. Estilo. Real. Transmissão. Letra.

A importância que Clarice Lispector confere ao indizível perpassa quase a totalidade de seus escritos. Mesmo que, em alguns momentos, o termo não surja expressamente, aparecem seus efeitos ou elucubrações acerca dele. Tal posição de destaque do tema é verificável no recorte aqui selecionado, composto pelos romances A paixão segundo G. H., Água viva, Um sopro de vida, A hora da estrela e pelo conto "O ovo e a galinha". Citemos algumas ocorrências:

Em $A$ paixão segundo $G$. $H$., encontramos um trecho paradigmático que favorece a compreensão da noção de indizível nessa fase da obra:

Eu tenho à medida que designo - este é o esplendor de se ter uma linguagem. Mas eu tenho muito mais à medida que não consigo designar. A realidade é a matéria prima, a linguagem é o modo como vou buscá-la - e como não acho. Mas é do buscar e não achar que nasce o que eu não conhecia, e que instantaneamente reconheço. A linguagem é meu esforço humano. Por destino tenho que ir buscar e por destino volto com as mãos vazias. Mas - volto com o indizível. O indizível só me poderá ser dado através do fracasso de minha linguagem. Só quando falha a construção, é que obtenho o que ela não conseguiu (LISPECTOR, 1998, p. 176).

Em Água viva, o termo aparece da seguinte maneira:

Foi uma sensação súbita, mas suavíssima. A luminosidade sorria no ar: exatamente isto. Era um suspiro do mundo. Não sei explicar, como não se sabe contar sobre a aurora a um cego. É indizível o que me aconteceu em forma de sentir: preciso depressa de tua empatia. Sinta comigo. Era uma felicidade suprema. (LISPECTOR, 1998a, p. 79).

Em Um sopro de vida, a palavra é utilizada em duas passagens para caracterizar a personagem Ângela:

Autor - Ela vive as diversas fases de um fato ou de um pensamento mas no mais fundo do seu interior é extra-situacional e no ainda mais fundo e inalcançável existe sem 
palavras, e é só uma atmosfera indizível, intransmissível, inexorável. Livre das velharias científicas e filosóficas (LISPECTOR, 1999, p. 49).

[...] Nesse nenhum lugar eu a deixo, já que ela tanto quer. E se encontrar o inferno em vida será ela própria a responsável por tudo. Se quiser seguir então me siga porque assim sou eu que mando e controlo. Mas não adianta mandar: essa criatura frívola que ama brilhantes e pérolas me escapa como escapa a ênfase indizível de um sonho (LISPECTOR, 1999, p. 56).

A hora da estrela não traz a palavra indizível em si mesma, mas não é necessário que o indizível apareça grafado para que o tema seja abordado por Clarice. É o que encontramos logo na primeira página da novela:

A verdade é sempre um contato interior e inexplicável. A minha vida a mais verdadeira é irreconhecível e não há uma só palavra que a signifique (LISPECTOR, 1999a, p. 11).

No conto "O ovo e a galinha", o termo indizível também não se registra, mas é possível detectar, através da figura do ovo, utilizada como instrumento de perfuração da escrita, um campo para além da palavra. A dúvida sobre a origem do ovo, reeditada a cada linha, aponta a inexistência da palavra primeira e, por conseguinte, indica a dimensão exterior às palavras. Não se trata de que algo poderia ter sido dito e não o foi, mas de uma ordem distinta, heterogênea à da palavra:

O ovo é basicamente um jarro? Terá sido o primeiro jarro moldado pelos etruscos? Não. O ovo é originário da Macedônia. Lá foi calculado, fruto da mais penosa espontaneidade. Nas areias da Macedônia um homem com uma vara na mão desenhou-o e depois apagou-o com o pé nu (LISPECTOR, 1998b, p. 51).

O indizível atinge o estatuto de noção para Clarice e baliza sua proposta poética conforme ela mesma faz questão de anunciar e esclarecer em diversos momentos de seu ofício literário. A impossibilidade de tudo exprimir tem, para a autora, o duplo valor de causa e finalidade da escrita. Seu exercício escritural resulta em sublinhar a existência desse campo que considera irrefutável. Mas as maneiras como Clarice lida com ele são variadas, e as nuances que se registram, nos referidos escritos, produzem alterações de estilo. O termo estilo se relaciona, então, na presente investigação da obra de Clarice, com o vórtice do indizível, mas as diferentes estratégias das quais a autora lança mão para dar-Ihe destaque também devem ser consideradas.

Outros significantes são parceiros do indizível, embora não se possa reduzir uns aos outros, na construção e revelação dos hiatos da escrita clariceana. Apenas para citar alguns, temos o inexpressivo, o neutro, o it, a coisa, o opaco, o insosso, o impossível, o invisível.

Clarice afirma sua preferência por criações artísticas que, de alguma forma, indicam esse território do indizível. Para alcançarem tal efeito, as referidas criações devem, segundo as convicções manifestadas pela autora em $A$ paixão segundo $G$. $H$., por exemplo, se eximir ao máximo da beleza e da expressividade. Esse tipo de assertiva surge, no entanto, em meio a uma escrita altamente expressiva da qual uma das marcas é a adjetivação abundante. O adjetivo comporta uma ambivalência em relação ao indizível: há uma necessidade de prescindir de adjetivar para que o indizível se escreva, pois se pretende que ele seja inqualificável e, ao mesmo tempo, o adjetivo é condição indelével para que o indizível marque o texto. A saída clariceana é substantivar o adjetivo e, assim, fala em o indizível, $o$ neutro, etc. Um desenvolvimento teórico a propósito desse processo de substantivação do adjetivo é encontrado em Roland Barthes (2003), quando aborda o tema do neutro. Para o autor, o adjetivo neutro, por ser qualificante, é um poderoso "contra-neutro", como se houvesse uma antipatia entre o neutro e o adjetivo. Conclui que o neutro demandaria, 
para ser explicitado diretamente, uma língua sem predicação, mas para abolir o paradigma sujeito / predicado a língua é obrigada a recorrer ao adjetivo substantivado por ser ele uma categoria difícil de "fichar"; por exemplo, é difícil fichar o úmido a não ser com a umidade.

A busca pelo impredicável revelada por Barthes tem um tempo necessário de passagem pela adjetivação e, em Clarice, esse tempo não é jamais abandonado, convivendo, do início ao fim da obra, com o indizível. Não se trata, a meu ver, de paradoxo entre o que pretende a escritora e o que se efetiva, mas do reconhecimento, por parte dela, das duas dimensões distintas anteriormente mencionadas.

$\mathrm{Na}$ maior parte dos escritos abordados, verifica-se que a autora elege determinados elementos aos quais delega a função de dar visibilidade ao indizível ou, em outras palavras, de transmiti-lo. Tais elementos atuam delineando um contorno sem o qual ele permaneceria indiferenciado, transportando, dessa maneira, porções do indizível para o escrito, embora ele não possa ser traduzido em palavras por pertencer a uma ordem distinta à delas. Por maior que seja o esforço, e por mais que se articulem, a diferença entre os dois campos permanecerá. Nesse ponto, seguimos de perto o que a própria autora propõe em "Escrever as entrelinhas":

Então escrever é o modo de quem tem a palavra como isca: a palavra pescando o que não é palavra. Quando essa não palavra morde a isca, alguma coisa se escreveu. Uma vez que se pescou a entrelinha, podia-se com alívio jogar a palavra fora. Mas aí cessa a analogia: a não palavra, ao morder a isca, incorporou-a. O que salva então é escrever distraidamente. (LISPECTOR, 1999, p. 385)

O termo transmissão, aqui utilizado para nomear o processo de registro do indizível nos escritos de Clarice, é tomado de empréstimo aos psicanalistas, quando eles se referem ao que ocorre em sua formação. Em relação aos escritos literários, propomos que transmitir significa dar passagem, por intermédio da palavra, a algo que está excluído do campo da linguagem. A crônica citada acima expõe de forma clara a concepção do indizível em Clarice, mas, como indicado anteriormente, os métodos de abordagem ocorrem de maneiras variadas. Vejamos o que se passa nos escritos selecionados.

Em cada um deles é possível designar um elemento central: em $A$ paixão segundo G. H., a posição de contornar o indizível é legada à barata, que, com sua imutabilidade, atravessa o texto. Esse tipo de inseto sempre esteve, para G.H., no âmbito do que é absolutamente exterior e que deve ser mantido fora por ser indesejável. O impacto causado pela presença inesperada da barata, vinda da escuridão funda do guarda-roupa, se deve em grande parte ao fato de ser sua existência imemorial. Aquela barata representa todas as outras que a antecedem há milênios; a característica mais ressaltada do inseto é a imutabilidade, que torna as baratas obsoletas e atuais. A reincidência do mesmo fragmenta a cadeia de associações significantes e revela os intervalos, pertencentes à ordem do indizível. $O$ surgimento da barata é acompanhado de uma sensação nomeada de "extremo gozo", que se relaciona, nesse romance, com a exposição do avesso. O contato com o lado antes oculto do inseto, possibilitado pelo rompimento de seu corpo, causado pela pancada da porta do armário, maximiza e radicaliza a idéia de uma dimensão exterior, desconhecida e renegada, pois se a barata já é considerada repugnante quando intacta, assim violada torna-se a imagem por excelência do abjeto. Uma possível reflexão sobre a linguagem em $A$ paixão segundo $G$. $H$. advém disso: assim como $G$. $\mathrm{H}$., Clarice lida com uma experiência que a leva para fora do mundo das significações. Trata-se, em seu caso, da experiência da escrita, capaz de produzir secções diversas. 
Tenciona falar dessas frinchas e, para isso, procura a melhor forma. Os vazios, todavia, a enredam. Diante do inevitável, passa ela própria a tentar conduzir o movimento em direção aos furos.

Processo semelhante ocorre com o ovo de "O ovo e a galinha." Ambos, barata e ovo, se aproximam estreitamente da coisa que não pode ser dita e, dessa forma, transmitem $\mathrm{O}$ indizível. $\mathrm{O}$ ovo é um significante que, tradicionalmente, remete à origem, à procriação, à fertilidade. No conto, há uma investigação a respeito da origem do próprio ovo, o que talvez possamos entender como a busca pelo marco zero, pela origem das origens. Chega-se à afirmativa de que o ovo se originou de um traço feito na areia, o qual, logo em seguida, foi apagado. A fugacidade do traço torna o ovo um objeto "impossível" e seu registro depende de que ele o seja. Mas, do mesmo modo que com a barata, alude-se ao status que tem o ovo de ser objeto cotidiano, e esse contraste entre suas existências, imemorial e banal, ressalta a impossibilidade de chegar a uma definição final a seu respeito. Cada uma de suas diversas aparições no escrito abre um novo furo que permite entrever o indizível.

Em Água viva, o objeto especial em destaque é a própria palavra, que revela sua dimensão de coisa. Comparativamente aos escritos anteriores, Água viva marca já um traço distintivo na maneira como a autora lida com o indizível e, portanto, um diferencial quanto ao estilo: em "O ovo e a galinha" e em $A$ paixão segundo $G$. H., apesar do reconhecimento de uma impossibilidade, a linguagem é também apontada como impotente para expressar o indizível, havendo mesmo a indicação de que, para tanto, é necessário dispensá-la. Água viva parte do princípio da impossibilidade de dizer o indizível, mas isso não impede que a narradora empreenda sua busca. 0 indizível se transforma, então, unicamente em potência que moverá a escrita.

Um sopro de vida parece mais diretamente voltado para a encenação da posição tomada pelo escritor diante do indizível: ele deve localizar-se no vazio para que a escrita se realize. A palavra com a qual tem que lidar é uma palavra, de saída, sucateada, desgastada, poluída. Não há, portanto, qualquer dúvida de que lhe é impossível apreender a coisa inominável. Ângela representa essa palavra quebradiça que, por isso mesmo, conduz o indizível ao escrito. Parece ter sido dado um passo além quanto à decisão pelo estilo indizível.

O ápice desse estilo será encontrado, a meu ver, em $A$ hora da estrela, em que essa linha de contorno do indizível, na figura de Macabéa, mostra-se em seu pleno paradoxo, qual seja o de uma afirmação inconteste e, ao mesmo tempo, inefável, que denuncia sua proximidade com o indizível. Semelhante ao que ocorre em relação à barata, ao ovo e à Ângela, a figura de Macabéa também ocupa uma posição de exterioridade e independência em relação aos outros elementos do texto. Ela se desagrega dos demais personagens, de si própria, da história. Suas relações são permeadas por uma separação iminente, e sua origem e seu fim se encerram nela mesma. As informações de que é órfã e de que seus ovários são murchos como cogumelos cozidos dão a dimensão dessa existência, da qual não se registra nem o passado, nem o futuro. Macabéa é resto, dejeto parco, fiapo. Tais características se coadunam com a intensa riqueza e força da personagem, inclusive no momento de queda suprema que é a morte. Essa performance se decalca perfeitamente ao projeto clariceano, em que os restos da operação da escrita são recolhidos por essa mesma escrita. Ao final, haverá sempre um resto não cooptado, e esse fato é tanto mais ressaltado quanto mais se busca a agregação das sobras.

A noção de letra, da qual aproximo diretamente os elementos citados anteriormente, quais sejam, o ovo, a barata, Ângela e Macabéa, é tratada por Lacan 
em diversos trabalhos ao longo de toda a sua obra, mas o ponto principal a ser retido, encontrado no artigo "Lituraterra" (2003), é a função, atribuída pelo autor à letra, de constituir um litoral entre os campos heterogêneos do Real e do Simbólico, permitindo que se comuniquem, mas mantendo cada qual em seu âmbito. É o que acredito serem capazes de realizar também os elementos clariceanos no que diz respeito ao indizível e à palavra.

Toda essa movimentação em torno do indizível fornece as bases da pesquisa do estilo em Clarice e, cabe recordar, essa última noção também convoca o ensino psicanalítico. Entretanto, para propor uma tal visão, é necessário percorrer a tradicional noção de estilo, conforme a concebe a disciplina Estilística. De acordo com esse ponto de vista, a expressividade é a palavra-chave do estilo, sua principal arma, conferindo ao texto a capacidade de emocionar e atrair a atenção de seu leitor. Herdeira da retórica clássica aristotélica, que estudava as mesmas propriedades referidas, no entanto, ao poder da oratória, a Estilística se debruça sobre a maneira de escrever. Esse fator não pode ser negligenciado em Clarice, mas, a meu ver, seu estilo o ultrapassa, pois escapa aos recursos expressivos utilizados pela autora. Para Lacan, o estilo é uma maneira de reencontrar o objeto opaco a partir do qual se tece o escrito. Em ambas as concepções, tanto de Lacan quanto de Clarice, o estilo não se resume a uma maneira de expressão; nem cabe considerá-lo uma consistência que possa ser apreendida a ponto de se tornar uma insígnia. O estilo trará sempre o reflexo dessa opacidade, desse resto inassimilável, indizível.

Verificando mais detidamente como essa última concepção de estilo opera na escrita de Clarice, chega-se aos seguintes resultados: em $A$ paixão segundo $G$. $H_{\text {., }}$ a autora encontra a perda a que o indizível conduz necessariamente, e procede à tentativa de preenchimento do vazio. Nesse romance, o mais antigo entre os analisados, o resto se sedimenta no tecido da escrita e transmite o indizível pelo jogo de forças opostas, pelo paradoxo de revelar a impossibilidade de falar do indizível na tentativa exasperada de fazê-lo.

Em Água viva, a posição da palavra ganha novo aspecto: a idéia é mostrar o indizível contido na própria palavra através do afastamento de seu significado em favor de sua vibração sonora, elemento que, isolado, é puramente físico.

Em Um sopro de vida, a vibração cede lugar ao sopro da respiração. A expressividade evoca mais uma vez o excesso, mas, dessa feita, através de uma coleção de fragmentos, diferindo de $A$ paixão segundo $G$. $H$.

O ápice do que viso designar como estilo de Clarice Lispector é encontrado em $A$ hora da estrela. Macabéa, da mesma forma que Ângela, não apenas parte em busca da coisa, como é, ela mesma, a própria coisa indizível. Aqui, a linguagem parece fazer uma trégua com o campo que se localiza para além dela. Macabéa é a personagem que se posiciona mais perto do indizível. Ela é a coisa opaca da escrita. A queda do objeto, representada por sua morte, é a prova de que Clarice abre mão da tentativa de fixá-lo no corpo do escrito; e é, finalmente, através do resto que sua escrita chega ao ponto de interrupção, com esse último romance, o qual a autora viu ser publicado. Assim, proponho designar de estilo do resto o riquíssimo estilo da última Clarice, mas sem apagar a possibilidade, verificada passo a passo, desde os textos mais antigos, de nomeá-lo também de estilo da vibração, estilo do excesso, estilo das entrelinhas ou, simplesmente, estilo do indizível. 
Abstract

The unspeakable is transmitted by specific elements in Clarice Lispector's writing, and the author's style moves around this transmission. It is possible to associate such terms as style, unspeakable, and transmission to the psychoanalytical idea of the Real and to detect in these elements a great similarity to the Lacanian idea of letter.

Key words: Unspeakable. Style. Real. Transmission. Letter.

\section{Referências}

BARTHES, Roland. O neutro. Tradução de Ivone Castilho Benedetti. São Paulo: Martins Fontes, 2003.

LACAN, Jacques. Lituraterra. In: _. Outros escritos. Tradução de Vera Ribeiro. Rio de Janeiro: Jorge Zahar, 2003. p. 15-25.

LISPECTOR, Clarice. A paixão segundo $G$. $H$. Rio de Janeiro: Rocco, 1998.

LISPECTOR, Clarice. Água viva. Rio de Janeiro: Rocco, 1998a.

LISPECTOR, Clarice. A descoberta do mundo. Rio de Janeiro: Rocco, 1999b.

LISPECTOR, Clarice. A hora da estrela. Rio de janeiro: Rocco, 1999a.

LISPECTOR, Clarice. O ovo e a galinha. In: clandestina. Rio de Janeiro: Rocco, 1998b. Felicidade

LISPECTOR, Clarice. Um sopro de vida. Rio de Janeiro: Rocco, 1999. 